\title{
UPAYA PENINGKATAN KEPUASAN KERJA DAN KINERJA KARYAWAN PERGURUAN TINGGI MELALUI MOTIVASI INTRINSIK DAN EKSTRINSIK
}

\author{
Musoli $^{1}$, Majang Palupi ${ }^{2}$ \\ ${ }^{1}$ Universitas Muhammadiyah Yogyakarta \\ musoli27@gmail.com \\ ${ }^{2}$ Universitas Islam Indonesia \\ majang_palupi@uii.ac.id
}

\begin{abstract}
This research aims at analyzing the infuence of intrinsic and extrinsic motivation toward work satisfaction and staff performance. The information gained from this research is crucial for the institution as a consideration to apply the increase of staff' performance. The subject of this research is the permanent educational personnel staffs of universities in Daerah Istimewa Yogyakarta. The technique of sample collecting applies the census method. The method of data collecting using survey method by distributing the questionnaires involves 104 respondents. The data is analyzed using Structural Equation Modeling (SEM) which is run through AMOS 21 program as the analysis tool. The research findings show that intrinsic motivation and extrinsic motivation have positive influence toward the work satisfaction. Then intrinsic motivation has a positif effect toward the work satisfaction, meanwhile extrinsic motivation does not have influence toward the work satisfaction, and the work satisfaction has a positive influence toward the work performance. Generally, this model is supported in field.
\end{abstract}

Keywords: Intrinsic Motivation, Extrinsic Motivation, Work Satisfaction, Work Performance

() 2018 JBTI. All rights reserved

Article history : received 27 Jul 2018; revised 20 Agt 2018; accepted 20 Sep 2018

\section{PENDAHULUAN}

Memasuki abad ke-21 ini banyak perubahan terjadi begitu cepat dalam semua bidang kehidupan. Perubahan tersebut berdampak besar terhadap perkembangan dan kemajuan suatu bangsa dan negara. Perubahan tersebut meliputi; politik, teknologi, pembangunan, sains, kedokteran, dan bidang-bidang lainya, semua perubahan tersebut tidak terlepas dari peran sumber daya manusia. Tidak dapat dipungkiri, untuk dapat mempunyai daya saing global, sumber daya manusia mempunyai peranan yang sangat penting. Peran yang dijalankan oleh sumber daya manusia dalam organisasi dapat memberikan sesuatu yang berharga bagi organisasi itu sendiri, terlebih jika organisasi tersebut mampu memberdayakan SDM-SDM didalamnya secara efektif dan efisien, maka tidak diragukan lagi organisasi tersebut dapat mencapai tujuannya.

Hal tersebut menuntut pemerintah untuk segera merespon dan minindaklanjut dalam mempersiapkan generasi bangsa yang mampu memajukan bangsa dan negara ini agar tidak tertinggal oleh bangsa-bangsa dan negara-negara lain. Pembangunan di segala bidang yang sedang dilakukan oleh pemerintah dalam upaya menuju kemajuan dan kemakmuran rakyat bangsa dan negara yang berorientasi pada peningkatan sumber daya manusia yang berkualitas. Didalam Sistem Pendidikan Nasional, pemerintah telah mengamanatkannya dalam Undang- 
Undang Pendidikan Nasional no. 20 Tahun 2003, tentang Sistem Pendidikan Nasional pada pasal 3 disebutkan, bahwa Pendidikan Nasional berfungsi mengembangkan kemampuan dan membentuk watak serta peradaban bangsa yang bermartabat dalam rangka mencerdaskan kehidupan bangsa. Ketetapan MPR No.IV tahun 1999, tentang GBHN, pada pasal 4 dijelaskan bahwa salah satu arah kebijaksanaan pembangunan nasional di bidang pendidikan pada ayat tujuh yaitu mengembangkan kualitas suber daya manusia sedini mungkin secara terarah, terpadu dan menyeluruh melalui berbagai upaya proaktif dan reaktif oleh seluruh komponen bangsa agar generasi muda dapat berkembang secara optimal disertai dengan hak dukungan dan lingkungan yang sesuai dengan potensinya agar peserta didik menjadi manusia yang beriman dan bertaqwa kepada Tuhan Yang Maha Esa, berakhlak mulia, sehat, berilmu serta bertanggung jawab.

Peraturan tersebut selanjutnya menjadi tanggung jawab bersama lembaga pendidikan baik sekolah maupun perguruan tinggi, karena bagaimanapun juga sekolah dan perguruan tinggi menjadi tonggak dalam mendidik generasi muda masa depan bangsa. Oleh karena itu perguruan tinggi untuk dapat merealisasikan dan mencapai mandat tersebut sudah tentu harus memiliki karyawan yang berkompeten memiliki motivasi tinggi dalam menjalankan sistem pendidikan yang mencerdaskan kehidupan bangsa. Untuk mendapatkan hal tersebut perguruan tinggi harus terus mengevaluasi dan memberikan kemampuan tambahan kepada seluruh karyawannya. Jika hal tersebut tidak dapat terpenuhi cepat atau lambat kualitas layanan pendidikan diperguruan tinggi tersebut akan menurun dan besar kemungkinan peserta didik akan berkurang. Hal tersebut harus segera diatisipasi mengingat tantangan kedepan perguruan tinggi semakin berat dengan semakin majunya era teknologi dan kebutuhan masyarakat.

Pada masa yang akan datang, harus disadari bahwa sumber daya manusia akan membutuhkan suatu model dan proses untuk memperoleh kecakapan dalam dunia global, keefektifan dalam bekerja dan kemampuan dalam berkompetisi. Menurut Putra dan Frianto, (2013) Sumber daya manusia merupakan salah satu unsur yang sangat menentukan keberhasilan suatu organisasi mencapai tujuan. Untuk mencapai tujuan organisasi maka hal yang perlu dilakukan adalah memberi daya pendorong yang mengakibatkan, menyalurkan dan memelihara perilaku karyawan agar bersedia bekerja sesuai dengan yang diinginkan organisasi. Daya pendorong tersebut disebut sebagai motivasi. Motivasi adalah proses yang menjelaskan intensitas, arah, dan ketekunan usaha untuk mencapai suatu tujuan (Robbins dan Judge, 2008).

Menurut teori yang dimaksud faktor motivasional adalah hal-hal yang mendorong berprestasi yang sifatnya intrinsik, yang berarti bersumber dalam diri seseorang, sedangkan yang dimaksud dengan faktor hygiene atau pemeliharaan adalah faktor-faktor yang sifatnya ekstrinsik yang berarti bersumber dari luar diri yang turut menentukan perilaku seseorang dalam kehidupan seseorang. Salah satu tantangan dalam memahami dan menerapkan teori Herzberg ialah memperhitungkan dengan tepat faktor mana yang lebih berpengaruh kuat dalam kehidupan seseorang, apakah yang bersifat intrinsik ataukah yang bersifat ekstrinsik (Luthans, 2006). Pentingya pengelolaan motivasi, baik motivasi intrinsik dan motivasi ekstrinsik karena akan menghasilkan kepuasan kerja. Kepuasan kerja bersangkutan dengan total sikap terhadap berbagai aspek pekerjaan proses dari hasil yang diperoleh dalam memenuhi harapan. Pegawai yang memiliki kepuasan kerja akan lebih produktif, memberikan kontribusi terhadap sasaran dan tujuan organisasi. (Robbins dan Judge, 2008) mengemukakan kepuasan kerja merupakan suatu perasaan positif tentang pekerjaan seseorang yang merupakan hasil dari evaluasi karakteristiknya.

Pimpinan perusahaan baik dalam organisasi yang berorientasi pada profit maupun non profit harus memperhatikan dan bertanggung jawab secara moral terhadap kepuasan kerja karyawannya karena kepuasan kerja karyawan yang tinggi akan mempunyai dampak terhadap peningkatan kinerja dan produktivitas karyawan dalam mencapai tujuan organisasi. Demikin pula dengan motivasi intrinsik penting karena motivasi intrinsik menyebabkan individu mau 
bekerja giat dan antusias mencapai hasil yang optimal sehingga dapat meningkatkan kinerja karyawan. Sama halnya denga motivasi ekstrinsik, motivasi ekstrinsik dapat ditempatkan sebagai bagian yang fundamental dari kegiatan manajemen, sehingga segala sesuatunya dapat ditunjukkan kepada pengarahan potensi dan daya kerja manusia dengan menimbulkan tingkat semangat dan kegairahan yang tinggi serta meningkatkan kebersamaan dalam menjalankan tugas individu maupun kelompok dalam suatu organisasi sehingga dapat meningkatkan kinerja karyawan yang optimal.

Berdasarkan latar belakang diatas peneliti mencoba menindaklanjuti rekomendasi dari beberapa penelitian terdahulu seperti, Budiyanto, dkk (2013); Putra, dkk (2013); Hayati dan Chaniago (2012); Budiyanto, dkk (2013); Putra, dkk (2013); Maulana dan Mayona (2015); Iriani (2010); Maulana dan Mayona (2015); Iriani (2010); Budianto, dkk (2013); Putra, dkk (2013); Taurisa dan Ratnawati (2012); Noor (2012) agar melakukan penelitian yang sama dan objek yang berbeda atau sampel yang berbeda guna memperkuat penelitian tersebut atau menyangkalnya.

\section{KAJIAN TEORI}

\section{A. Pengertian Motivasi}

Motivasi sebagai proses yang menjelaskan intensitas, arah dan ketekunan seorang individu untuk mencapai tujuanya. Sementara motivasi umum berkaitan dengan usaha mencapai tujuan apa pun, dengan mempersempit fokus tersebut menjadi tujuan-tujuan organisasional untuk mencerminkan minat karyawan terhadap prilaku yang berhubungan dengan pekerjaan (Robbins dan Judge, 2008).

Teori yang dikembangkan oleh Hezberg dikenal dengan "Model Dua Faktor" dari motivasi, yaitu faktor motivasional dan faktor hygiene atau "pemeliharaan". Menurut teori ini yang dimaksud faktor motivasional adalah hal-hal yang mendorong berprestasi yang sifatnya intrinsik, yang berarti bersumber dalam diri seseorang, sedangkan yang dimaksud dengan faktor hygiene atau pemeliharaan adalah faktor-faktor yang sifatnya ekstrinsik yang berarti bersumber dari luar diri yang turut menentukan perilaku seseorang dalam kehidupan seseorang. Salah satu tantangan dalam memahami dan menerapkan teori Herzberg ialah memperhitungkan dengan tepat faktor mana yang lebih berpengaruh kuat dalam kehidupan seseorang, apakah yang bersifat intrinsik ataukah yang bersifat ekstrinsik (Luthans, 2006).

\section{B. Motivasi Intrinsik}

Menurut Handoko (2001) motivasi intrisik yaitu motivasi atau dorongan yang timbul dari dalam diri individu sendiri tanpa ada paksaan dari orang lain, melainkan atas dasar kemauan sendiri. contohnya: Self actualization need (keinginan untuk mengaktualisasikan diri). Motivasi intrinsik adalah pendorong kerja yang bersumber dari dalam diri pekerja sebagai individu berupa kesadaran mengenai pentingya atau manfaat atau makna pekerjaan yang dilaksanakanya. dengan kata lain motivasi ini bersumber dari pekerjaan yang dilaksanakanya baik karena mampu memenuhi kebutuhan atau menyenangkan atau memungkinkan mencapai suatu tujuan maupun karena memberi harapan tertentu yang positif di masa depan. Misalnya pekerjaan yang bekerja secara berdedikasi semata-mata karena merasa memperoleh kesempatan untuk mengaktualisasikan atau mewujudkan realisasi dirinya secara maksimal (Nawawi, 2001).

Menurut Herzberg yang dikutip oleh Luthans (2006); Hidayat \& Tjahjono (2015) dan Pangesti et al. (2013), motivasi intrinsik adalah motivasi yang mendorong seseorang untuk berprestasi yang bersumber dalam diri individu tersebut, yang lebih dikenal dengan faktor motivasional. 


\section{Motivasi Ekstrinsik}

Motivasi ekstrinsik adalah dorongan yang timbul sebagai akibat pengaruh dari luar individu, apakah karena adanya stimmulus atau rangsangan, suruhan atau bahkan paksaan dari orang lain, sehingga dalam kondisi demikian seorang mau melakukan sebuah tindakan atau pekerjaan contohnya: reward dan punishment Handoko (2001). Motivasi ekstrinsik bersumber dari luar diri individu sehingga seseorang mau melakukan sesuatu tindakan. Motivasi ekstrinsik adalah pendorong kerja yang bersumber dari luar diri pekerja sebagai individu berupa suatu kondisi yang mengharuskannya melaksanakan pekerjaan secara maksimal. Misalnya berdedikasi tinggi dalam bekerja karena upah atau gajih yang tinggi, jabatan atau posisi yang terhormat atau memiliki kekuasaan yang besar, pujian, hukuman (Nawawi, 2001).

Menurut Herzberg yang dikutip oleh Luthans (2006) Motivasi ekstrinsik adalah motivasi yang bersumber dari luar diri yang turut menentukan perilaku seseorang dalam kehidupan seseorang yang dikenal dengan teori hygiene factor.

\section{Kepuasan Kerja}

Menurut Locke yang dikutip oleh Luthans (2006) memberikan definisi komprehensif dari kepuasan kerja yang meliputi reaksi atau sikap kognitif, afektif, dan evaluatif dan menyatakan bahwa kepuasan kerja adalah "keadaan emosi yang senang atau emosi positif yang berasal dari penilaian pekerjaan atau pengalaman kerja seseorang." Kepuasan kerja adalah hasil dari persepsi karyawan mengenai seberapa baik pekerjaan mereka memberikan hal yang dinilai penting.

Kepuasan kerja (Job Satisfaction), yaitu suatu perasaan positif tentang pekerjaan seseorang yang merupakan hasil dari evaluasi karakteristiknya. Kepuasan kerja lebih menggambarkan sikap dari pada prilaku. Definisi ini benar-benar merupakan sebuah definisi yang sangat luas. Ingat pekerjaan seseorang lebih dari sekedar aktivitas mengatur kertas, menulis kode program, menunggu pelanggan, atau mengendarai sebuah truk. Setiap pekerjaan menuntut interaksi dengan rekan kerja dan atasan-atasan, mengikuti peraturan dan kebijaksanaan-kebijaksanaan organisasional, memenuhi standar-standar kinerja, menerima kondisi-kondisi kerja yang acap kali kurang ideal dan lain-lain. ini berarti bahwa penilaian seorang karyawan tentang seberapa ia merasa puas atau tidak puas dengan pekerjaan merupakan penyajian yang rumit dari sejumlah elemen pekerjaan yang berlainan (Robbins dan Judge, 2008).

\section{E. Kinerja Karyawan}

Ada beberapa pendapat mengenai pengertian kinerja. Dalam kamus besar bahasa indonesia, kinerja diartikan sebagai "prestasi yang diperlihatkan". Sedangkan kata kinerja dalam bahasa inggris adalah "performance". Arti kata performance adalah suatu hasil yang telah dikerjakan. Kinerja didefinisikan sebagai hubungan antara hasil kerja nyata dengan harapan yang telah ditetapkan sebelumnya atau perbandingan dengan hasil yang dicapai oleh orang lain Wilcoxon (2000, dalam Waluyo, 2015) sedangkan menurut Gomes (2000, dalam Waluyo, 2015) menyatakan kinerja "the record of produced on a spesified job function or activity during a spesified time period", hal tersebut dapat dijelaskan bahwa kinerja merupakan catatan outcome yang dihasilkan dari sebuah pekerjaan khusus tertentu atau kegiatan selama priode waktu tertentu.

Kinerja merupakan istilah yang berasal dari kata Job Performance atau Actual Performance (prestasi kerja atau prestasi sesungguhnya dicapai seseorang). Kinerja (prestasi kerja) adalah "hasil kerja secara kualitas dan kuantitas yang dicapai seorang pegawai dalam melaksanakan tugasnya sesuai dengan tanggung jawab yang diberikan kepadanya" Mangkunegara (2009). 


\section{F. Pengembangan Hipotesis}

Motivasi intrinsik merupakan sifat seseorang karyawan bukan karena tuntutan tugasnya atau pun pekerjaanya, namun berdasarkan pada keinginan untuk terus menjadi lebih baik. Tentu hal ini karyawan memberikan nilai tambah bagi organisasi tersebut. Value Added yang diberikan oleh karyawan yang memiliki motivasi intrinsik yang tinggi tentu akan meningkatkan kepuasan kerja. Demikian halnya dalam penelitian Budiyanto, dkk (2013); Putra, dkk (2013); Hayati dan Chaniago (2012) menyatakan bahwa motivasi intrinsic memiliki pengaruh positif terhadap kepuasan kerja dengan semakin meningkatnya motivasi intrinsik karyawan dan semakin meningkatnya kepuasan kerja karyawan maka keduanya mempunyai pengaruh positif. Berdasarkan beberapa penelitian tersebut maka dirumuskan hipotesis pertama penelitian sebagai berikut:

$\mathbf{H}_{\mathbf{1}}$ : Motivasi intrinsik berpengaruh signifikan terhadap kepuasan kerja.

Motivasi ekstrinsik memiliki peranan yang kuat untuk mendorong keberhasilan karyawan dalam menyelesaikan semua pekerjaanya atau tugas-tugasnya. Tentu hal ini karyawan memberikan nilai tambah bagi organisasi tersebut. Value Added yang diberikan oleh karyawan yang memiliki motivasi ekstrinsik yang tinggi tentu akan meningkatkan kepuasan kerja. Demikian halnya dalam penelitian Budiyanto, dkk (2013); Putra, dkk (2013) menyatakan bahwa motivasi ekstrinsik memiliki pengaruh positif terhadap kepuasan kerja dengan semakin meningkatnya motivasi ekstrinsik karyawan dan semakin meningkatnya kepuasan kerja karyawan maka keduanya mempunyai pengaruh positif. Dengan demikian berdasarkan penelitian tersebut hipotesis kedua penelitian sebagai berikut:

$\mathbf{H}_{2}$ : Motivasi ekstrinsik berpengaruh signifikan terhadap kepuasan kerja.

Motivasi intrinsik penting karena motivasi intrinsik menyebabkan individu mau bekerja giat dan antusias mencapai hasil yang optimal. Organisasi tidak hanya mengharapkan kemampuan, dan keterampilan, tetapi yang terpenting adalah kemauan bekerja dengan giat dan berkeinginan untuk mencapai hasil kerja yang maksimal. Kemampuan dan kecakapan karyawan tidak ada artinya, jika tidak ada kemauan untuk bekerja. Tujuan dari motovasi intrinsik adalah jika berhasil dicapai akan meningkatkan kinerja karyawan atau memenuhi kebutuhan- kebutuhan tersebut. Dan seberapa kuat motivasi intrinsik yang dimiliki individu akan banyak menentukan kualitas perilaku yang ditampilkannya, baik dalam konteks sebuah kantor atau orgnisasi maupun dalam kehidupan lainnya. Demikian halnya dalam penelitian Maulana dan Mayona (2015); Iriani (2010) menyatakan bahwa motivasi intrinsic berpengaruh positif terhadap kinerja karyawan dengan semakin meningkat motivasi intrinsik karyawan dan semakin meningkatnya kinerja karyawan maka keduanya mempunyai pengaruh positif. Dengan demikian berdasarkan penelitian tersebut hipotesis ketiga penelitian sebagai berikut:

$\mathbf{H}_{3}$ : Motivasi intrinsik berpengaruh signifikan terhadap kinerja karyawan.

Motivasi ekstrinsik dapat ditempatkan sabagai bagian yang fundamental dari kegiatan manajeman, sehingga segala sesuatunya dapat ditunjukkan kepada pengarahan potensi dan daya kerja manusia dengan menimbulkan tingkat semangat dan kegairahan yang tinggi serta meningkatkan kebersamaan dalam menjalankan tugas individu maupun kelompok dalam suatu organisasi. Dalam hubungan ini pelaksanaan tugas atau pekerjaan yang dibebankan kepadanya maka motivasi berperan sebagai pendorong kemauan dan keinginan untuk bekerja menurut ukurannya. Hal tersebut sejalan dengan penelitian Maulana dan Mayona (2015); Iriani (2010) yang menyatakan motivasi ekstrinsik memiliki pengaruh positif terhadap kinerja karyawan dengan semakin meningkatnya motivasi ekstrinsik karyawan dan semakin meningkatnya kinerja karyawan maka keduanya mempunyai pengaruh positif. Dengan demikian berdasarkan penelitian tersebut hipotesis keempat penelitian sebagai berikut: 
$\mathbf{H}_{4}$ : Motivasi ekstrinsik berpengaruh signifikan terhadap kinerja karyawan.

Pimpinan perusahaan baik dalam organisasi yang berorientasi pada profit maupun non profit harus memperhatikan dan bertanggung jawab secara moral terhadap kepuasan kerja karyawannya karena kepuasan kerja karyawan yang tinggi akan mempunyai dampak terhadap peningkatan kinerja dan produktivitas karyawan dalam mencapai tujuan organisasi. Demikian halnya dalam penelitian Budianto, dkk (2013); Putra, dkk (2013); Taurisa dan Ratnawati (2012); Noor (2012); Tjahjono \& Riniarti (2015) menyatakan bahwa kepuasan kerja memiliki pengaruh positif terhadap kinerja karyawan dengan semakin meningkatnya kepuasan kerja karyawan dan semakin meningkatnya kinerja karyawan maka keduanya mempunyai pengaruh positif. Dengan demikian berdasarkan penelitian tersebut hipotesis kelima penelitian sebagai berikut:

$\mathbf{H}_{5}$ : $\quad$ Kepuasan kerja berpengaruh signifikan terhadap kinerja karyawan.

\section{G. Model Penelitian}

Model penelitian yang diajukan dalam penelitian ini terdiri dari tiga variabel yaitu motivasi intrinsik dan motivasi ekstrinsik sebagai variabel independen, dan kepuasan kerja sebagai variable intervening serta kinerja karyawan sebagai variabel dependen. Model penelitian ini dapat digambarkan sebagai berikut:

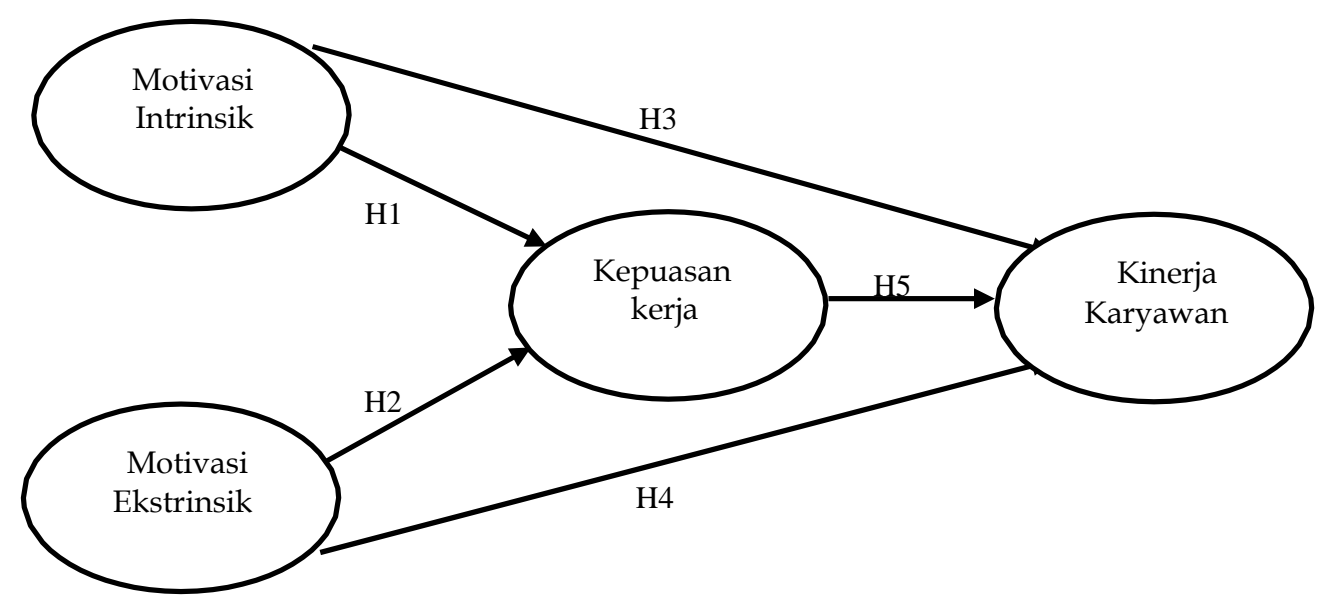

Gambar 1

Model Penelitian

\section{METODE PENELITIAN}

\section{A. Populasi, Obyek dan Subyek Penelitian}

Dalam penelitian ini populasi yang digunakan mencakup karyawan tenaga kependidikan tetap Universitas Muhammadiyah Yogyakarta pada bagian fakultas. Obyek dalam penelitian ini adalah Universitas Muhammadiyah Yogyakarta yang terletak di Jalan Lingkar Selatan, Tamantirto, Kasihan, Bantul, Yogyakarta dan subyek dalam penelitian ini adalah karyawan tetap tenaga kependidikan pada fakultas di Universitas Muhammadiyah Yogyakarta.

\section{B. Jenis dan Sumber Data}

Jenis data yang digunakan dalam penelitian ini adalah data primer yaitu data yang diperoleh dari sumber asli atau tanpa menggunakan media perantara dari responden atau obyek yang diteliti melalui daftar pertanyaan (kuisioner) yang telah disediakan peneliti. Data primer diperoleh melalui penyebaran kuesioner. 


\section{Teknik Pengumpulan Data}

Teknik pengumpulan data yang digunakan dalam penelitian ini yaitu menggunakan metode survey dengan menyebarkan kuesioner. Pengiriman kuesioner dalam penelitian ini diserahkan langsung kepada responden peneliti. Daftar pertanyaan dibuat dengan menggunakan skala Likert $1 \mathrm{~s} / \mathrm{d} 5$.

\section{Definisi Operasional Variabel Penelitian}

Berikut ini definisi operasional variabel-variabel yang akan diteliti:

Tabel. 1 Definisi Operasional Variabel

\begin{tabular}{|c|c|c|}
\hline Variabel Laten & Pengertian & Indikator Variabel \\
\hline $\begin{array}{l}\text { Motivasi intrinsik } \\
\text { (variabel laten } \\
\text { bebas) }\end{array}$ & $\begin{array}{l}\text { Motivasi intrinsik adalah motivasi yang } \\
\text { mendorong seseorang untuk berprestasi } \\
\text { yang bersumber dalam diri individu } \\
\text { tersebut, yang lebih dikenal dengan faktor } \\
\text { motivasional. }\end{array}$ & $\begin{aligned} & \text { 1. } \text { Pencapaian prestasi } \\
& \text { 2. } \text { Pengakuan } \\
& \text { 3. } \text { Tanggungjawab } \\
& \text { 4. } \text { Kemajuan } \\
& \text { 5. } \text { Pekerjaan itu sendiri } \\
& \text { 6. } \text { Kemungkinan berkembang } \\
& \text { (Sumber : Gibson, 2002). }\end{aligned}$ \\
\hline $\begin{array}{l}\text { Motivasi ekstrinsik } \\
\text { (variabel laten } \\
\text { bebas) }\end{array}$ & $\begin{array}{l}\text { Motivasi ekstrinsik adalah motivasi yang } \\
\text { bersumber dari luar diri yang turut } \\
\text { menentukan perilaku seseorang dalam } \\
\text { kehidupan seseorang yang dikenal dengan } \\
\text { teori hygiene factor. }\end{array}$ & $\begin{aligned} & \text { 1. } \text { Upah } \\
& \text { 2. } \text { Keamanan kerja } \\
& \text { 3. } \text { Kondisi kerja } \\
& \text { 4. } \text { Status } \\
& \text { 5. } \text { Prosedur perusahaan } \\
& \text { 6. } \text { Mutu penyelia } \\
& \text { 7. Mutu hubungan iterpersonal } \text { antar sesama rekan kerja, } \\
& \text { atasan dan bawahan } \\
& \text { (Sumber : Gibson, 2002) }\end{aligned}$ \\
\hline $\begin{array}{l}\text { Kepuasan kerja } \\
\text { (variabel } \\
\text { Intervening) }\end{array}$ & $\begin{array}{l}\text { kepuasan kerja adalah "keadaan emosi } \\
\text { yang senang atau emosi positif yang } \\
\text { berasal dari penilaian pekerjaan atau } \\
\text { pengalaman kerja seseorang. }\end{array}$ & $\begin{array}{cl}\text { 1. } & \text { Pekerjaan itu sendiri } \\
\text { 2. } & \text { Gaji } \\
\text { 3. } & \text { Kesempatan promosi } \\
\text { 4. } & \text { Pengawasan } \\
\text { 5. } & \text { Rekan kerja } \\
\text { (Sumber Luthans, 2006) }\end{array}$ \\
\hline $\begin{array}{l}\text { Kinerja karyawan } \\
\text { (Variabel laten } \\
\text { terikat) }\end{array}$ & $\begin{array}{l}\text { Kinerja (prestasi kerja) adalah "hasil kerja } \\
\text { secara kualitas dan kuantitas yang dicapai } \\
\text { seorang pegawai dalam melaksanakan } \\
\text { tugasnya sesuai dengan tanggung jawab } \\
\text { yang diberikan kepadanya" }\end{array}$ & $\begin{array}{l}\text { 1. Kualitas } \\
\text { 2. Kuantitas } \\
\text { 3. Ketepatan waktu } \\
\text { 4. Keberhasilan kerja (Sumber } \\
\text { :Robbinas, 2006) }\end{array}$ \\
\hline
\end{tabular}

\section{HASIL PENELITIAN DAN PEMBAHASAN}

\section{A. Uji Kualitas Instrumen dan Data Uji Validitas}

Validitas merupakan pengujian yang menunjukkan sejauh mana alat pengukur yang kita guanakan mampu mengukur apa yang ingin kita ukur dan bukan mengukur yang lain. Uji validitas diuji dengan program AMOS 21 dengan melihat output estimate dengan cara membandingkan $p$-value pada output estimate dengan alpha 5\%, jika $p$-value lebih kecil dari $5 \%$ maka indikator dinyatakan valid Ghozali (2013).

Validitas diuji dengan program AMOS dengan melihat output estimate dengan cara membandingkan p-value pada output estimate dengan alpha 5\%, jika p-value lebih kecil dari $5 \%$ maka indikator dinyatakan valid. Berdasarkan hasil uji validitas menunjukkan bahwa 
semua indikator memiliki loading factor $<0,50$ sehingga hasil perhitungan tersebut telah memenuhi validitas atau dinyatakan valid.

\section{Uji Reliabilitas}

Reliabilitas merupakan pengujian yang menunjukkan sejauhmana stabilitas dan konsistensi dari alat pengukur yang digunakan, sehingga memberikan hasil yang relatif konsisten jika pengkuran tersebut diulangi. Pengukuran realibilitas didasarkan pada indeks numerik yang disebut koefisien. Dalam penelitian pengujian kualitas data yang sering dilakukan adalah uji reliabilitas untuk reliabilitas konsistensi internal. Dikatakan reliabilitas jika nilai cronbach alpha > 0,7 (Ghozali, 2013).

Hasil empiris dapat dilihat pada Tabel 2 yang menunjukkan bahwa keseluruhan item reliabel atau konsisten sebagai alat ukur.

Tabel. 2 Hasil Uji Reliabilitas

\begin{tabular}{|l|c|c|}
\hline \multicolumn{1}{|c|}{ Nama Variabel } & $\begin{array}{c}\text { Hasil Uji Reliabilitas } \\
\text { /Construct Reliablity }\end{array}$ & Keterangan \\
\hline Motivasi Intrinsik & 0,811354 & Reliabel \\
\hline Motivasi Ekstrinsik & 0,795848 & Reliabel \\
\hline Kepuasan Kerja & 0,89142 & Reliabel \\
\hline Kinerja Karyawan & 0,95592 & Reliabel \\
\hline
\end{tabular}

Sumber : Data Diolah 2016

\section{B. Uji Asumsi SEM}

\section{Jumlah Sampel}

Jumlah sampel yang digunakan dalam penelitian ini adalah 104 sampel dimana jumlah tersebut dapat dikategorikan ke dalam sampel besar dan telah memenuhi rule of thumb.

\section{Uji Outlier}

\section{Multivariate Outlier}

Evaluasi terhadap multivariate outliers dapat dilihat melalui output AMOS mahalanobis distance. Kriteria yang digunakan pada tingkat $\mathrm{p}<0,001$. Jarak tersebut dievaluasi dengan menggunakan $\mathrm{X}^{2}$ pada derajat bebas sebesar jumlah variabel terukur yang digunakan dalam penelitian. Jumlah indikator dalam penelitian ini adalah 53, kemudian melalui program excel dengan CHIINV hasilnya adalah 87,96798.

Hasil uji multivariate outliers memberikan hasil bahwa seluruh observation number pada data yang dimasukkan dalam model penelitian memiliki nilai mahalanobis $d$-square < 87,96798 sehingga dapat dikatakan bahwa seluruh data dapat digunakan dan lolos pengujian outlier sehingga tidak ada satu data pun yang harus dikeluarkan dari model penelitian.

\section{Uji Normalitas}

Uji normalitas dilakukan dengan melihat nilai critical ratio (c.r) untuk kurtosis (keruncingan) maupun skewness (kemencengan) dengan nilai kritis $\pm 2,58$ pada level 0,01 (Ferdinand, 2006). Sedangkan secara multivariate dapat dilihat pada c.r. baris terakhir dengan ketentuan yang sama. 
Hasil output dari uji normalitas menunjukkan bahwa data menggunakan kriteria critical ratio sebesar $\pm 2,58$ pada tingkat signifikansi 0,01 (1\%) (Ghozali, 2013). Hasil ada 25 indikator yang tidak memiliki nilai antara -2,58 sampai 2,58. Dan ada 26 indikator yang memiliki nilai antara -2,58 sampai 2,58. Oleh karena itu dapat disimpulkan bahwa ada 25 indikator berdistribusi tidak normal dan ada 26 indikator yang berdistribusi normal. Sehingga dapat disimpulkan bahwa uji normalitas data berdistribusi secara normal. Hair et al (1995) dalam Ghozali (2013) menyatakan bahwa data yang normal secara multivariate pasti normal secara univariate.

\section{E. Hasil Respon Kuesioner dan Karakteristik Responden}

Subyek penelitian ini adalah karyawan tetap tenaga kependidikan Universitas Muhammadiyah Yogyakarta sebanyak 115 orang. Kuesioner yang disebar secara langsung dalam penelitian ini sebanyak 115 kuesioner dan yang kembali sebanyak 115 sehingga response rate sebesar $90,4 \%$.

Berdasarkan pengumpulan data dilapangan melalui pengumpulan jawaban kuesioner yang diperoleh dari responden, maka diperoleh gambaran mengenai karakteristik responden berdasarkan jenis kelamin, usia, unit kerja, lama bekerja dan pendidikan sebagai berikut: karakteristik responden laki-laki berjumlah 67,3\% atau 70 orang, sementara responden perempuan berjumlah $19,2 \%$ atau 20 orang. Sedangkan yang tidak menyebutkan ada $13,5 \%$ atau 14 orang. karakteristik usia responden karyawan tetap UMY untuk kategori usia 20-30 tahun berjumlah $6,7 \%$ atau 7 orang, usia 31-41 tahun berjumlah 7,7\% atau 8 orang, usia $42-52$ tahun berjumlah $45,2 \%$ atau 47 orang, usia 53-63 tahun berjumlah 12,5\% atau 13 orang, usia 64-74 berjumlah $1,0 \%$ atau 1 orang. Sedangkan yang tidak menyebutkan ada 26,9\% atau 28 orang.

karakteristik unit kerja responden karyawan tetap UMY untuk FAI berjumlah 4,8\% atau 5 orang, FE berjumlah 9,6\% atau 10 orang, FH berjumlah 8,7 atau 9 orang, FKIK berjumlah 17,3 atau 18 orang, FPB berjumlah 1,9\% atau 2 orang, FP berjumlah 9,6\% atau 10 orang, FT berjumlah 13,5\% atau 14 orang, FISIPOL berjumlah 12,5\% atau 13 orang, Pascasarjana berjumlah 3,8\% atau 4 orang. Sedangkan yang tidak menyebutkan ada 3,8\% atau 4 orang. karakteristik lama bekerja responden karyawan tetap UMY untuk responden yang telah bekerja dari 1-5 tahun berjumlah $7,7 \%$ atau 8 orang, sementara responden yang telah bekerja lebih dari 5 tahun berjumlah $73 \%$ atau 76 orang. Sedangkan yang tidak menyebutkan ada $19,2 \%$ atau 20 orang.

karakteristik tingkat pendidikan responden karyawan tetap UMY untuk tingkat SLTP berjumlah 1,9\% atau 2 orang, SLTA berjumlah 45,2\% atau 47 orang, D3 berjumlah 8,7\% atau 9 orang, S1 berjumlah 26,0\% atau 27 orang, S2 berjumlah 1,0\% atau 1 orang. Sedangkan yang tidak menyebutkan ada $17,3 \%$ atau 18 orang.

\section{F. Deskripsi Variabel Penelitian}

Statistik deskriptif responden dalam memberikan penilaian variabel motivasi intrinsik. Variabel motivasi intrinsik menunjukkan jumlah rata-rata 3,958317 dengan skor minimum ada di item peryataan X1.1, yaitu peluang karir diuniversitas merupakan sumber motivasi dalam bekerja. Sedangkan skor maksimum ada di item pernyataan X1.4, yang menunjukkan bahwa karyawan suka pekerjaan yang bertumpu pada kemajuan.

Motivasi ekstrinsik menunjukkan jumlah rata-rata 3,924457 dengan skor minimum ada di item pernyataan X2.1, yaitu memiliki kesempatan mendapatkan gaji/upah yang tinggi diuniversitas. Sedangkan skor maksimum ada di item pernyataan X2.5, yang menunjukkan bahwa saya merasa bangga menjadi karyawan tetap universitas ini. 
Kepuasan kerja menunjukkan jumlah rata-rata 3,72741 dengan skor minimum ada di item pernyataan X3.15, yaitu atasan selalu memberikan pujian pada saya atas kerja yang saya selesaikan. Sedangkan skor maksimum ada di item pernyataan X3.8, yang menunjukkan bahwa rekan kerja saya memberikan bantuan langsung dalam menyelesaikan pekerjaan.

Kinerja karyawan menunjukkan jumlah rata-rata 4,178845 dengan skor minimum ada di item pernyataan Y.6, yaitu saya sanggup menerima resiko terhadap tugas yang diberikan kepada saya. Sedangkan skor maksimum ada di item pernyataan Y.18, yang menunjukkan bahwa saya cenderung untuk menjalankan ajaran islam.

\section{G. Pengujian Hipotesis}

Analisis dari hasil pengolahan data pada full model SEM dilakukan dengan melakukan uji kesesuaian dan uji statistik. Hasil pengujian dengan menggunakan metode SEM ditunjukkan pada gambar 1 dibawah ini.

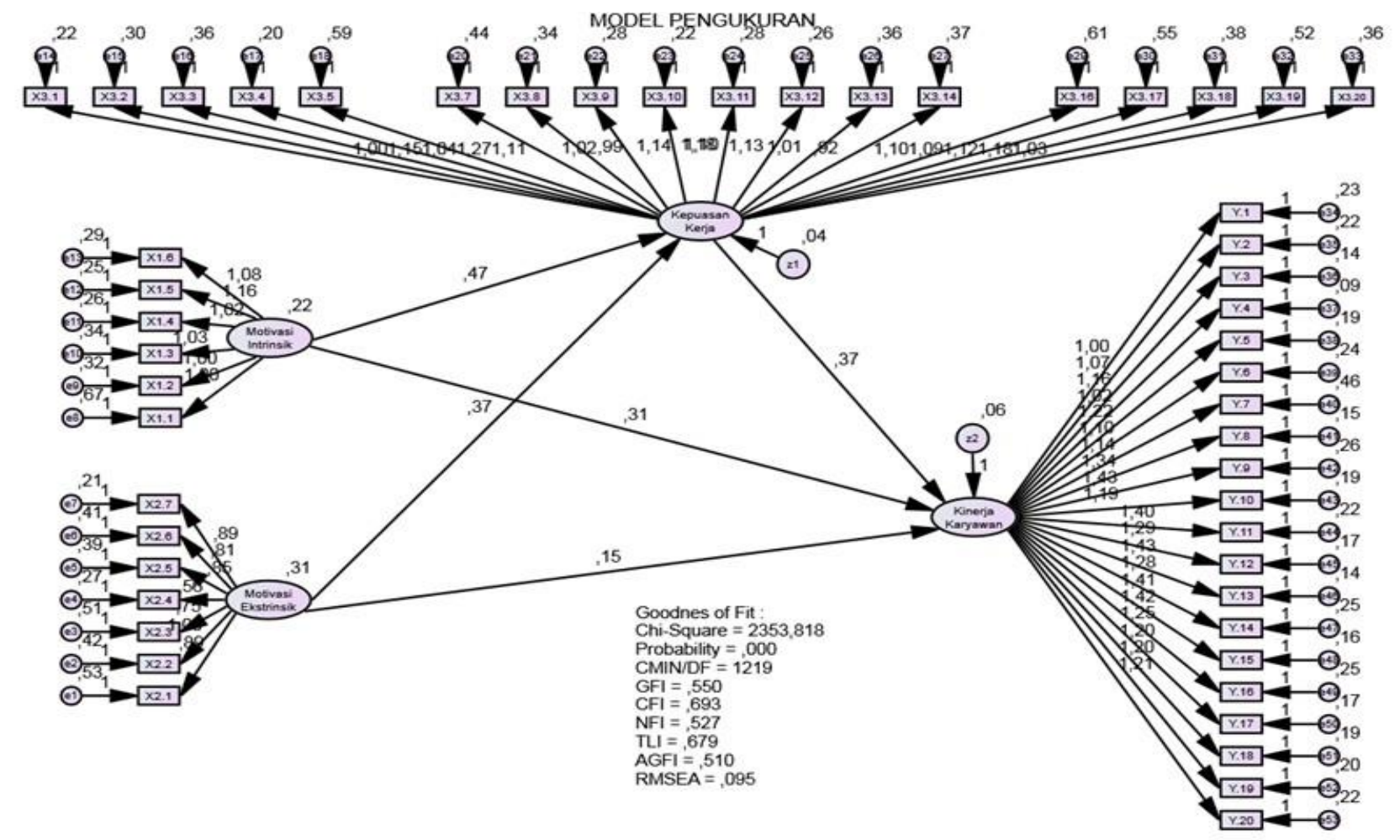

Sumber : Data diolah 2016

Gambar 2. Full Model SEM

Hasil perhitungan melalui analisis faktor konfirmatori dan structural equation model, menyatakan bahwa model dalam penelitian ini dapat diterima. Hasil pengukuran telah memenuhi kriteria goodness of fit yaitu Chi- square $=2353,818$, Probability $=0,000$; $\mathrm{CMIN} / \mathrm{DF}=1,219 ; \mathrm{GFI}=0,591 ; \mathrm{CFI}=0,693 ; \mathrm{NFI}=0,527$; TLI $=0,679 ; \mathrm{AGFI}=0,510$ dan RMSEA $=0,005$. Hasil secara lengkap pengukuran Structural Equation Model (SEM) seperti pada Tabel 2. 
Tabel. 3 Pengukuran Indeks Pengujian Kelayakan (Goodness Of Fit) Pengaruh Motivasi Intrinsik Dan Motivasi Ekstrinsik Terhadap Kepuasan Kerja Dan Kinerja Karyawan

\begin{tabular}{|l|c|c|c|}
\hline \multicolumn{1}{|c|}{ Goodness of Fit } & $\begin{array}{c}\text { Hasil } \\
\text { Analisis }\end{array}$ & $\begin{array}{c}\text { Cut-off } \\
\text { Value }\end{array}$ & $\begin{array}{c}\text { Keterang } \\
\text { an }\end{array}$ \\
\hline$X^{2}$ (Chi-Square) & 2353,818 & $<321,417$ & Marginal \\
\hline Probability & 0,000 & $\square 0,05$ & Kurang \\
\hline CMIN/DF & 1,219 & $\leq 2$ & Fit \\
\hline GFI & 0,550 & $\square 0,90$ & Marginal \\
\hline AGFI & 0,510 & $\square 0,90$ & Marginal \\
\hline NFI & 0,527 & $\square 0,90$ & Marginal \\
\hline TLI & 0,679 & $\square 0,90$ & Marginal \\
\hline CFI & 0,693 & $\square 0,95$ & Marginal \\
\hline RMSEA & 0,095 & $\leq 0,08$ & Marginal \\
\hline
\end{tabular}

Sumber : Data diolah 2016

Berdasrkan tabel 3,dapat dilihat hasil Goodness of fit diperoleh nilai Chi-Squar, Probability, GFI, AGFI, NFI, TLI, CFI dan RMSEA menunjukkan model belum fit karena nilainya belum sesuai dengan nilai yang direkomendasikan, namun, perlu dilihat kriteria fit yang lain untuk menyimpulkan Goodness of Fit overall model, nilai CMIN/DF menunjukkan model fit sesuai dengan nilai yang direkomendasikan. selain itu (Ghozali, 2013) juga menyatakan bahwa jika terdapat satu atau dua kriteria Goodness of Fit yang telah memenuhi, model dikatakan baik.

Hasil pengujian Goodness of fit secara keseluruhan dapat disimpulkan bahwa kelayakan model SEM sudah cukup memenuhi syarat penerimaan.

Tabel. 4 Hasil Uji Hipotesis

\begin{tabular}{|c|c|c|c|c|c|c|}
\hline & & Estimate & S.E. & C.R. & $\mathrm{P}$ & keterangan \\
\hline Kepuasan_Kerja & <--- Motivasi_Intrinsik & ,471 &, 125 & 3,778 & $* * *$ & signifik \\
\hline Kepuasan_Kerja & <--- Motivasi_Ekstrinsik & ,369 & ,085 & 4,346 & $* * *$ & $\operatorname{ran}$ \\
\hline Kinerja_Karyawan & <--- Motivasi_Intrinsik & ,309 &, 130 & 2,376 & ,018 & signifikan \\
\hline Kinerja_Karyawan & <--- Motivasi_Ekstrinsik &, 152 & ,092 & 1,646 & , 100 & Tidak signifikan \\
\hline Kinerja_Karyawan & <--- Kepuasan_Kerja & ,373 &, 184 & 2,027 &, 043 & signifikan \\
\hline
\end{tabular}

Sumber : Data diolah 2016

Tabel tersebut memperlihatkan bahwa empat hipotesis menunjukkan p.value kurang dari 0,05 yang berarti bahwa hipotesis 1 , hipotesis 2 , hipotesis 3 , hipotesis 5 , signifikan dan 1 hipotesis menunjukkan p.value lebih dari 0,05 yang berarti bahwa hipotesis 4 tidak signifikan. Hipotesis 6 dan hipotesis 7 adalah untuk melihat pengaruh tidak langsung motivasi intrinsik dan motivasi ekstrinsik terhadap kinerja karyawan melalui kepuasan kerja.

Berdasarkan hasil uji hipotesis, Motivasi intrinsik dan motivasi ektrinsik terhadap kinerja karyawan yang dilihat dari standardized direct effects motivasi intrinsik $(0,381)$, motivasi ektrinsik $(0,226)$ dengan standardized indirect effects motivasi intrinsik $(0,217)$, motivasi ektrinsik $(0,205)$. Berdasarkan data tersebut dapat digunakan untuk mengetahui hubungan antara pengaruh motivasi intrinsik dan motivasi ektrinsik yang dimediasi oleh variabel kinerja karyawan, dengan demikian hubungan tidak langsung antara motivasi intrinsik dan motivasi ektrinsik terhadap kepuasan kerja tidak signifikan. Oleh karena itu kepuasan kerja tidak memediasi dalam pengaruh hubungan tersebut. Untuk melihat apakah variabel kepuasan kerja memediasi hubungan antara variabel motivasi intrinsik dan motivasi 
ekstrinsik terhadap kinerja karyawan, yaitu dengan cara membandingkan nilai standardized direct effects dan standardized indirect effects. Artinya jika nilai standardized direct effects lebih kecil dari nilai standardized indirect effects maka dapat dikatakan bahwa variabel mediasi tersebut mempunyai pengaruh secara tidak langsung dalam hubungan kedua variabel tersebut (independen dan dependen).

\section{H.Pembahasan}

Hipotesis pertama (H1) berbunyi: "Motivasi intrinsik berpengaruh signifikan terhadap kepuasan kerja". Berdasarkan hasil pengujian membuktikan bahwa variabel motivasi intrinsik berpengaruh positif dan signifikan terhadap variabel kepuasan kerja. Hal ini berarti bahwa semakin tinggi motivasi intrinsik yang dimiliki karyawan maka akan mempengaruhi tingkat kepuasan kerja. Demikian pula sebaliknya semakin rendah tingkat motivasi intrinsik yang dimiliki karyawan maka semakin rendah tingkat kepuasan kerja. Artinya, hubungan antara motivasi intrinsik karyawan yang bersumber dari dalam diri karyawan tersebut mempengaruhi kepuasan kerja. Hal ini berarti hipotesis pertama yang diajukan dalam penelitian ini yang menyatakan motivasi intrinsik berpengaruh signifikan terhadap kepuasan kerja terdukung.

Bahwa motivasi intrinsik berpengaruh dengan kepuasan kerja. Hal ini untuk menunjukkan bahwa faktor- faktor motivasi yang bersifat internal dengan Pencapaian prestasi, Pengakuan, Tanggungjawab, Kemajuan, Pekerjaan itu sendiri dan Kemungkinan berkembang secara signifikan berhubungan dengan kepuasan kerja karyawan. Maka variabel motivasi intrinsik menjadi variabel yang penting untuk dipertimbangkan oleh institusi dalam meningkatkan kepuasan kerja.

Hasil penelitian ini sejalan dengan hasil penelitian Hayati and Caniago, (2012), Putra, $d k k$ (2013), Budianto, $d k k$ (2013), bahwa motivasi intrinsik berpengaruh positif signifikan terhadap kepuasan kerja.

Hipotesis kedua (H2) berbunyi: "Motivasi ekstrinsik berpengaruh signifikan terhadap kepuasan kerja". Berdasarkan hasil pengujian membuktikan bahwa variabel motivasi ekstrinsik berpengaruh positif dan signifikan terhadap variabel kepuasan kerja. Hal ini berarti bahwa semakin tinggi motivasi ekstrinsik yang dimiliki karyawan maka akan mempengaruhi tingkat kepuasan kerja. Demikian pula sebaliknya semakin rendah tingkat motivasi intrinsik yang dimiliki karyawan maka semakin rendah tingkat kepuasan kerja. Artinya, hubungan antara motivasi ekstrinsik karyawan perguruan tinggi yang bersumber dari luar diri karyawan tersebut mempengaruhi kepuasan kerja. Hal ini berarti hipotesis kedua yang diajukan dalam penelitian ini yang menyatakan motivasi ekstrinsik berpengaruh signifikan terhadap kepuasan kerja terdukung.

Bahwa motivasi ekstrinsik berpengaruh dengan kepuasan kerja. Hal ini untuk menunjukkan bahwa faktor- faktor motivasi yang bersifat eksternal dengan Upah, Keamanan kerja, Kondisi kerja, Status, Prosedur perusahaan, Mutu penyeliaan, Mutu hubungan interpersonal antar sesama rekan kerja, atasan dan bawahan secara signifikan berhubungan dengan kepuasan kerja karyawan perguruan tinggi. Maka variabel motivasi ekstrinsik menjadi variabel yang penting untuk dipertimbangkan oleh institusi dalam meningkatkan kepuasan kerja yang dimiliki oleh karyawan perguruan tinggi.

Hasil penelitian ini sejalan dengan hasil penelitian Budianto, $d k k$ (2013) dan Putra, $d k k$ (2013), bahwa motivasi ekstrinsi berpengaruh positif signifikan terhadap kepuasan kerja.

Hipotesis ketiga (H3) berbunyi: "Motivasi intrinsik berpengaruh signifikan terhadap kinerja karyawan". Berdasarkan hasil pengujian membuktikan bahwa variabel motivasi intrinsik berpengaruh positif dan signifikan terhadap variabel kinerja karyawan. Hal ini berarti 
bahwa semakin tinggi motivasi intrinsik yang dimiliki karyawan maka akan mempengaruhi tingkat kinerja karyawan. Demikian pula sebaliknya semakin rendah tingkat motivasi intrinsik yang dimiliki karyawan maka semakin rendah tingkat kinerja karyawan. Artinya, hubungan antara motivasi intrinsik karyawan perguruan tinggi yang bersumber dari dalam diri karyawan tersebut mempengaruhi tingkat kinerja karyawan. Hal ini berarti hipotesis ketiga yang diajukan dalam penelitian ini yang menyatakan motivasi intrinsik berpengaruh signifikan terhadap kinerja karyawan terbukti.

Bahwa motivasi intrinsik berpengaruh dengan kinerja karyawan. Hal ini untuk menunjukkan bahwa faktor- faktor motivasi yang bersifat internal dengan Pencapaian prestasi, Pengakuan, Tanggungjawab, Kemajuan, Pekerjaan itu sendiri dan Kemungkinan berkembang secara signifikan berhubungan dengan kinerja karyawan perguruan tinggi. Maka variabel motivasi intrinsik menjadi variabel yang penting untuk dipertimbangkan oleh institusi dalam meningkatkan kinerja karyawan yang dimiliki oleh karyawan perguruan tinggi.

Hasil penelitian ini sejalan dengan hasil penelitian Maulana, dkk (2015) dan Iriani, (2010), bahwa motivasi intrinsik berpengaruh positif signifikan terhadap kinerja karyawan.

Hipotesis keempat (H4) berbunyi: "Motivasi ekstrinsik berpengaruh signifikan terhadap kinerja karyawan". Berdasarkan hasil pengujian membuktikan bahwa variabel motivasi ekstrinsik tidak berpengaruh signifikan terhadap variabel kineja karyawan. Hal ini berarti bahwa semakin tinggi motivasi ekstrinsik yang dimiliki karyawan maka tidak akan mempengaruhi tingkat kinerja karyawan. Demikian pula sebaliknya semakin rendah tingkat motivasi ekstrinsik yang dimiliki karyawan maka tidak mempengaruhi tingkat kinerja karyawan. Artinya, hubungan antara motivasi ekstrinsik karyawan perguruan tinggi yang bersumber dari luar diri karyawan tersebut tidak mempengaruhi tingkat kinerja karyawan. Hal ini berarti hipotesis keempat yang diajukan dalam penelitian ini yang menyatakan motivasi ekstrinsik berpengaruh signifikan terhadap kinerja karyawan tidak terdukung.

Bahwa motivasi ekstrinsik tidak berpengaruh dengan kinerja karyawan. Hal ini untuk menunjukkan bahwa faktor-faktor motivasi yang bersifat eksternal dengan Upah, Keamanan kerja, Kondisi kerja, Status, Prosedur perusahaan, Mutu penyeliaan, Mutu hubungan interpersonal antar sesama rekan kerja, atasan dan bawahan secara tidak signifikan tidak berhubungan dengan kinerja karyawan perguruan tinggi. selain itu dengan banyaknya usia karyawan perguruan tinggi yang sudah mendekati masa pensiun menjadikan para karyawan tersebut sudah tidak terlalu antusias dalam meningkatkan kinerjanya. Apalagi dengan kondisi saat ini perguruan tinggi semakin terus berkembang dengan begitu banyaknya tantangantantangan yang harus dihadapi.

Maka variabel motivasi ekstrinsik menjadi variabel yang tidak terlalu penting untuk dipertimbangkan oleh institusi dalam meningkatkan kinerja karyawan yang dimiliki oleh karyawan perguruan tinggi. Hasil penelitian ini tidak sejalan dengan hasil Maulana, $d k k$ (2015) dan Iriani, (2010), bahwa motivasi ekstrinsi berpengaruh positif signifikan terhadap kinerja karyawan.

Hipotesis kelima (H5) berbunyi: "kepuasan kerja berpengaruh signifikan terhadap kinerja karyawan". Berdasarkan hasil pengujian membuktikan bahwa variabel kepuasan kerja berpengaruh positif dan signifikan terhadap variabel kineja karyawan. Hal ini berarti bahwa semakin tinggi kepuasan kerja yang dimiliki karyawan maka akan mempengaruhi tingkat kinerja karyawan. Demikian pula sebaliknya semakin rendah tingkat kepuasan kerja yang dimiliki karyawan maka mempengaruhi tingkat kinerja karyawan. Hal ini berarti hipotesis kelima yang diajukan dalam penelitian ini yang menyatakan kepuasan kerja berpengaruh positif signifikan terhadap kinerja karyawan terdukung. 
Bahwa kepuasan kerja berpengaruh dengan kinerja karyawan. Hal ini untuk menunjukkan bahwa faktor- faktor kepuasan kerja dengan Rekan Kerja, Gaji, Kesempatan Promosi, Pengawasan dan Pekerjaan itu sendiri secara signifikan berhubungan dengan kinerja karyawan tenaga kependidikan tetap universitas muhammadiyah yogyakarta. Maka variabel kepuasan kerja menjadi variabel yang penting untuk dipertimbangkan oleh institusi dalam meningkatkan kinerja karyawan yang dimiliki oleh karyawan perguruan tinggi.

Hasil penelitian ini sejalan dengan hasil penelitian Budianto, $d k k$ (2013), Putra, $d k k$ (2013), Taurisa, $d k k$ (2012), Noor, (2012), bahwa kepuasan kerja berpengaruh positif signifikan terhadap kinerja karyawan.

\section{KESIMPULAN, SARAN DAN KETERBATASAN}

Berdasarkan hasil penelitian yang telah dilakukan tentang pengaruh motivasi intrinsik dan motivasi ekstrinsik terhadap kepuasan kerja dan kinerja karyawan, dapat disimpulkan Motivasi intrinsik mempunyai pengaruh secara positif dan signifikan terhadap kepuasan kerja. Hal ini menunjukkan bahwa motivasi intrinsik yang dimiliki karyawan tinggi. Dan hasil penelitian ini didukung dengan hasil penelitian yang dilakukan oleh Budianto, $d k k$ (2013), Putra, $d k k$ (2013) dan Hayati dan Caniago (2012).

Motivasi ekstrinsik mempunyai pengaruh secara positif dan signifikan terhadap kepuasan kerja. Hal ini menunjukkan bahwa motivasi ekstrinsik yang dimiliki karyawan tinggi. Dan hasil penelitian ini didukung dengan hasil penelitian yang dilakukan oleh Budianto, $d k k$ (2013) dan Putra, $d k k$ (2013).

Motivasi intrinsik mempunyai pengaruh secara positif dan signifikan terhadap kinerja karyawan. Hal ini menunjukkan bahwa motivasi intrinsik yang dimiliki karyawan tinggi. Dan hasil penelitian ini didukung dengan hasil penelitian yang dilakukan oleh Maulana, $d k k$ (2015) dan Iriani, (2010).

Motivasi ekstrinsik mempunyai pengaruh secara positif dan tidak signifikan terhadap kinerja karyawan. Hal ini menunjukkan bahwa seberapa tinggi motivasi ekstrinsik yang dimiliki karyawan tidak memengaruhi kinerja karyawan. Dan hasil penelitian ini tidak sejalan dengan hasil penelitian yang dilakukan oleh Maulana, $d k k$ (2015) dan Iriani, (2010).

Kepuasan kerja mempunyai pengaruh secara positif dan signifikan terhadap kinerja karyawan. Hal ini menunjukkan bahwa kepuasan kerja yang dimiliki karyawan tinggi. Dan hasil penelitian ini didukung dengan hasil penelitian yang dilakukan oleh Budianto, $d k k$ (2013), Putra, $d k k$ (2013), Taurisa, $d k k$ (2012) dan Noor, (2012).

Keterbatasan Penelitian ini tidak semua responden atau karyawan tenaga kependidikan tetap Universitas Muhammadiyah Yogyakarta mengembalikan kuesioner penelitian sehingga perlu diperbanyak lagi atau menyeluruh ke karyawan tetap agar lebih representatif. Serta kempat variabel yang diteliti masih dirasa belum cukup untuk mengukur variabel yang dapat mempengaruhi kinerja karyawan.

Saran Akademik Penelitian ini supaya memperluas atau menyeluruhkan sampel penelitian yang lebih representatif dan Menambah variabel penelitian atau variabel yang lebih relevan untuk mengukur kinerja karyawan. Sedangkan saran praktik, hasil penelitian ini menunjukkan bahwa motivasi intrinsik dan motivasi ekstrinsik terhadap kepuasan kerja dan kinerja karyawan dinilai baik, sehingga institusi perlu untuk memperhatikan variabel- variabel yang dapat mempengaruhi kinerja karyawan agar kinerja karyawan terus meningkat. 


\section{DAFTAR PUSTAKA}

Budianto, Ferdinan, dan Sambung, R., (2013), Pengaruh Pengaruh Motivasi Intrinsik dan Motivasi Ekstrinsik Terhadap Kinerja Pegawai Melalui Kepuasan Kerja (Studi Pada Universitas Palangka Raya), no. 2, vol. 2, hal. 78-88.

Ferdinand, A, (2006), Metode Penelitian Manajemen: Pedoman Penelitian untuk skripsi, Tesis dan Disertai Ilmu Manajemen. Semarang: Universitas Diponegoro.

Ghozali, I., (2013), Konsep dan Aplikasi dengan Program AMOS 21.0, Edisi 5, Badan Penerbit Universitas Diponegoro, Semarang.

Gibson, J, L., Ivancevich, John M., Donnely, James H., (2002). Organisasi. Edisi Delapan. Binarupa Aksara. Tangerang.

Handoko, T. H., (2001). Manajemen Personalia dan Sumber Daya Manusia. Yogyakarta: BPFE Yogyakarta.

Hayati, K., dan Caniago, I., (2012), "Islamic Work Ethic: The Role of Intrinsic Motivation, Job Satisfaction, Organizational Commitment and Job Performance”, Procedia- Social and Behavioral Sciences, FE- Universitas Lampung, Bandar Lampung, hal.273-277.

Hidayat, S. \& Tjahjono, H.K. (2015). Peran Etika Kerja Islam dalam mempengaruhi Motivasi Intrinsik, Kepuasan Kerja dan Dampaknya terhadap Komitmen Organisasional (studi empiris pada pondok pesantren modern di Banten). Jurnal Akuntansi dan Manajemen Akmenika, 12(2): 625-637.

Iriani Nur Ida, (2010), Motivasi Intrinsik, Motivasi Ekstrinsik dan Disiplin Kerja Pengaruhnya terhadap Kinerja Pegawai pada Kantor Dinas Pendidikan Kabupaten Sambas, Jurnal Aplikasi Manajemen, no. 2, vol. 8, hal. 561-569.

Luthans, F., (2006), Prilaku Organisasi, Edisi 10, Yogyakarta, ANDI Yogyakarta.

Mangkunegara, Anwar Prabu., (2009). Manajemen Sumber Daya Manusia Perusahaan. Bandung: PT Remaja Rosdakarya.

Maulana, Fakhrian, Harza, Hamid, Djamhur, dan Mayoan, Yuniadi, (2015), "Pengaruh Motivasi Intrinsik, Motivasi Ekstrinsik dan Komitmen Organisasi Terhadap Kinerja Karyawan pada Bank BTN Kantor Cabang Malang, Jurnal Administrasi Bisnis (JAB), no. 1, vol. 22, hal. 18.

Nawawi, H. Hadari, (2001), Manajemen Sumber Daya Manusia, Jakarta, Gadjah Mada University Press.

Noor, zainul, Arifin, (2012), Pengaruh Budaya Organisasi, Komiten Organisasi, dan Motivasi Kerja terhadap Kepuasan Kerja dan Kinerja Karyawan, Jurnal Ekonomi dan Keuangan, no.4, Vol.16, hal. 473-486.

Pangesti, G.R., Tjahjono, H.K., Maryati, T. (2013). The Influences of Transformational Leadership, Motivation Factor and Hygiene Factor Toward Job Satisfaction of Balai Besar Latihan Ketransmigrasian Yogyakarta's Employee. Jurnal Bisnis teori dan Implementasi, 4(1): 3144.

Putra, A., Kamajaya dan Frianto, A., (2013), "Pengaruh Motivasi Intrinsik dan Motivasi Ekstrinsik Terhadap Kepuasan Kerja, Jurnal Ilmu Manajemen, no. 1, vol. 1, hal. 377-387.

Robbins, S, P., dan Timothy A, J., (2008), Perilaku Organisasi, Edisi 12 Jilid 1 dan 2, Jakarta: Salemba Empat. Santoso, S., (2001), Buku Latihan SPSS Statistik Parametrik. Penerbit PT. Elex Media Komputindo, Kelompok Gramedia, Jakarta. 
TAP MPR No.IV/MPR/1999, Ketetapan MPR Tentang Garis-Garis Haluan Negara Tahun 19992004, Undang- Undang Republik Indonesia Nomor 20 Tahun 2003, Sistem Pendidikan Nasional, Jakarta, CV Eko Jaya.

Taurisa, Melina, Chaterina dan Ratnawati, Intan, (2012), Pengaruh Budaya Organisasi dan Kepuasan Kerja Terhadap Komitmen Organisasional dalam meningkatkan Kinerja Karyawan, Jurnal Bisnis dan Ekonomi, MM-UNDIP, no.2, hal. 170-183.

Tjahjono, H.K. \& Riniarti (2015). Evaluasi Keadilan Praktik Tunjangan Kinerja Pada Kepuasan dan Kinerja Karyawan di Kantor BPS DIY. Jurnal Siasat Bisnis, 19(2): 124-131.

Waluyo, B, A., (2015), "Pengaruh Budaya Organisasi, Kepemimpinan Trasformasional, dan Motivasi terhadap Kinerja Pegawai Pada Sekretariat DPRD Kabupaten Gunung Kidul”, MM Pascasarjana UMY, Yogyakarta, hal.11-12. 